\title{
The Empirical Analysis of Higher Vocational Education Regional Competitive Advantage in China \\ -- Based on the Comparative Study of 31 Provinces and Cities in China
}

\author{
Luo Weiwei ${ }^{1, a,{ }^{*}}$ Su Yinghong ${ }^{2, b}$ \\ ${ }^{1}$ Department of Finance and Accounting, Xiamen City Vocational College, \\ Fujian Xiamen,361005 \\ 2 Quality Control Office Xiamen City Vocational College, \\ Fujian Xiamen,361005 \\ aweiwei@xmcu.cn, byinghong@xmcu.cn
}

\begin{abstract}
Keywords: Higher vocational education; Competitiveness; Entropy weight method; Gray relative analysis method;

Abstract. This article evaluates, sorts and classifies regional higher vocational competitiveness of 31 provinces and cities in China with entropy weight method and gray relative analysis method and did a comparative study. The result shows that the region with the highest score of regional higher vocational competitiveness focus on the eastern provinces like Jiangsu and Zhejiang, and lower ranking regions are western regions which mainly include Qinghai and Xizang. The paper conclusion helps to put forwards the countermeasures for balanced development of regional higher vocational education in China.
\end{abstract}

\section{Literature Review}

Education and human capital are one of the most important factors to weigh a country's comprehensive national strength. Its competitiveness is an important symbol of a country's comprehensive national strength. Early domestic research is mainly to compare the educational competitiveness of China and other countries in the world, such as Sun Jingshui(2001) ${ }^{[1]}$; after that, some scholars turn the research object to domestic comparison and study the competitiveness of regional education at the provincial level, such as $\mathrm{Wu}$ Yuming $(2002)^{[2]}$.

Due to the rapid development of vocational education and the important function of complementary communication with ordinary education, many scholars have actively carried out relevant research in this field. Representative literature is the one which Chen Yan et al. (2009) measured from the aspects of structure, quality, benefit, scale, opportunity and investment ${ }^{[3]}$. Fang Yong (2016) compared the gap between China and Switzerland on the competitiveness of vocational education. He believes that the difference between the two countries is mainly because of whether there is a complete vocational education system and characteristic vocational education model, as well as the attention to technical skills talents ${ }^{[4]}$; Hu Binwu et al.(2017) did an analysis on the development of secondary vocational education in 31 provinces in China, and found that although the vocational education has developed rapidly in the last decade, there are some problems in the aspects of regional equilibrium and efficiency ${ }^{[5]}$. However, in terms of the competitiveness of higher vocational education, more literature takes individual colleges as the research object, and seeks the advantages and disadvantages of the competitiveness of schools through the comparison between colleges and universities, such as Cui Kuiyong, Zhao Sasa (2012) ${ }^{[6]}$, Qiu Junping, Chai Wen $(2017)^{[7]}$ et al. It is rare to see literature discuss the relationship between higher vocational education and regional social development by comparing the competitiveness of higher vocational education among regions.

Therefore, this paper intends to construct a multi angle and multi-level evaluation system of 
regional vocational education competitiveness through the quality annual report and educational statistics of Higher Vocational Education in the framework of competitiveness theory and evaluation system, and carries out an empirical comparison and analysis.

\section{The Construction of the Evaluation Index System of Competitiveness of Higher Vocational Education}

Regional higher vocational education competitiveness refers to the space in a certain range, compared with other regions, the comparative advantages higher vocational education has, including three aspects like regional economic development environment, the scale of higher vocational education, higher vocational education quality. In order to ensure accuracy and impartiality of the evaluation results, to ensure the availability of data, and follow the principles of science, system, comprehensiveness and comparability, this article designs and makes a selection of the higher vocational education competitiveness evaluation index system, a total of three first-level indicators, 11 secondary indexes. The indicator system is shown in table 1 . The data are derived from the statistics of China Statistical Yearbook 2015, China Education Statistical Yearbook 2015, China Education Financial Statistics Yearbook 2015 and the annual quality reports.

Table 1 Evaluation index system of the competitiveness of higher vocational education

\begin{tabular}{|c|c|c|c|c|}
\hline & grade I index & grade II index & Index connotation & Index explanation \\
\hline \multirow{11}{*}{$\begin{array}{l}\text { Evaluation index } \\
\text { system of the } \\
\text { competitiveness } \\
\text { of Higher } \\
\text { Vocational } \\
\text { Education }\end{array}$} & \multirow{4}{*}{$\begin{array}{l}\text { Regional Economic } \\
\text { Developing } \\
\text { Environment }\end{array}$} & Per capita GDP X1 & $\begin{array}{c}\text { Reflects regional } \\
\text { output level Per } \\
\text { capita }\end{array}$ & $\begin{array}{l}\text { GDP/Regional average } \\
\text { population }\end{array}$ \\
\hline & & $\begin{array}{l}\text { local financial revenue } \\
\qquad \mathrm{X} 2\end{array}$ & $\begin{array}{l}\text { Reflects the } \\
\text { economic strength of } \\
\text { local governments }\end{array}$ & $\begin{array}{l}\text { The higher this index is, } \\
\text { the stronger the ability of } \\
\text { government input or } \\
\text { expenditure in local } \\
\text { education }\end{array}$ \\
\hline & & $\begin{array}{l}\text { total export-import of } \\
\text { goods volume } \\
\text { propotion } \\
\text { X3 }\end{array}$ & $\begin{array}{l}\text { Reflects regional } \\
\text { trade level }\end{array}$ & $\begin{array}{l}\text { total export-import } \\
\text { volume/GDP }\end{array}$ \\
\hline & & $\begin{array}{c}\text { The number of } \\
\text { industrial enterprises } \\
\text { above state designated } \\
\text { scale X4 }\end{array}$ & $\begin{array}{l}\text { Reflects degree of } \\
\text { regional } \\
\text { industrialization }\end{array}$ & \\
\hline & \multirow{4}{*}{$\begin{array}{l}\text { Higher vocational } \\
\text { education scale }\end{array}$} & $\begin{array}{l}\text { Number of higher } \\
\text { vocational school } \\
\text { X5 } \\
\end{array}$ & $\begin{array}{c}\text { Reflects the amount } \\
\text { of higher vocational } \\
\text { education }\end{array}$ & \\
\hline & & $\begin{array}{c}\text { Number of outstanding } \\
\text { teacher } \\
\text { X6 }\end{array}$ & $\begin{array}{l}\text { Reflects human input } \\
\text { scale }\end{array}$ & \\
\hline & & $\begin{array}{c}\text { Number of graduate } \\
\text { X7 } \\
\end{array}$ & $\begin{array}{l}\text { Reflects educational } \\
\text { output scale }\end{array}$ & \\
\hline & & $\begin{array}{c}\text { average education } \\
\text { expenditure } \\
\text { X8 } \\
\end{array}$ & $\begin{array}{l}\text { Reflects funding } \\
\text { scale }\end{array}$ & $\begin{array}{c}\text { educational funds } \\
\text { expenditure/number of } \\
\text { current students }\end{array}$ \\
\hline & \multirow{3}{*}{$\begin{array}{l}\text { Higher vocational } \\
\text { education quality }\end{array}$} & $\begin{array}{l}\text { model vocational } \\
\text { college propotion } \\
\text { X9 }\end{array}$ & $\begin{array}{l}\text { Reflects regional } \\
\text { higher vocational } \\
\text { education level }\end{array}$ & $\begin{array}{c}\text { Number of model } \\
\text { vocational college/number } \\
\text { of Regional vocational } \\
\text { college }\end{array}$ \\
\hline & & $\begin{array}{l}\text { Number of key major } \\
\text { and model major X10 }\end{array}$ & $\begin{array}{l}\text { Reflects professional } \\
\text { education quality }\end{array}$ & \\
\hline & & $\begin{array}{c}\text { Number of excellent } \\
\text { course X11 }\end{array}$ & $\begin{array}{l}\text { Reflects course } \\
\text { teaching quality }\end{array}$ & \\
\hline
\end{tabular}




\section{Empirical Analysis of Regional Higher Vocational Education Competitiveness}

\subsection{Empirical Approach}

This article uses entropy weight method and gray relative analysis method as the basic methods to measure competitiveness.

\subsection{1 entropy weight method}

Entropy weight method is an objective method of empowerment. After data preprocessing ${ }^{1}$, calculating the degree of deviation of sample values. The greater the difference, the greater the evaluation function of the index, so the greater the weight given. To calculate the entropy value of item J:

$$
\begin{aligned}
& H_{j}=-k \sum_{i=1}^{m} f_{i j} \ln f_{i j},(j=1,2, \ldots, n) \\
& k=\frac{1}{\ln n}, f_{i j}=\frac{r_{i j}}{\sum_{i=1}^{m} r_{i j}}
\end{aligned}
$$

Then calculate the entropy weight of item $\mathrm{J}$,

$$
w_{j}=\frac{1-H_{j}}{n-\sum_{j=1}^{n} H_{j}},(j=1,2, \ldots, n)
$$

\subsection{2 gray relative analysis method}

Select a set of reference columns (In this article, the maximum value of each index makes up the Reference Series), calculate the absolute difference between the index sequence and the reference sequence of each evaluation object, and determine the two groups of arrays:

$$
\begin{gathered}
\min _{i=1}^{m}\left\{\min _{j=1}^{n}\left(\left|r_{i j}-r_{0 j}\right|\right)\right\} \\
\max _{i=1}^{m}\left\{\max _{j=1}^{n}\left(\left|r_{i j}-r_{0 j}\right|\right)\right\}
\end{gathered}
$$

Among them, $\left\{r_{0 j}\right\}, j=1,2, \ldots, n$ is a reference sequence.

Calculate the correlation coefficients between the sequences and the reference sequences according to the relevance theory:

$$
\theta_{i j}=\frac{\min _{i=1}^{m}\left\{\min _{j=1}^{n}\left(\left|r_{i j}-r_{0 j}\right|\right)\right\}+\rho \max _{i=1}^{m}\left\{\max _{j=1}^{n}\left(\left|r_{i j}-r_{0 j}\right|\right)\right\}}{\left(r_{0 j}-r_{i j}\right)+\rho \max _{i=1}^{m}\left\{\max _{j=1}^{n}\left(\left|r_{i j}-r_{0 j}\right|\right)\right\}}
$$

Among them, resolution factor value $\rho$ as $0.5 ; \theta_{i j}$ reflects the correlation degree between the $i^{\text {th }}$ evaluation object and the reference sequence on the $j^{\text {th }}$ index. To further analyze the degree of correlation between the evaluation object and the reference sequence, we need to make weighted summation of the correlation degree. The weights are determined according to the entropy method.

$$
\theta_{i}=\sum_{j=1}^{n} w_{j} \theta_{i j}
$$

$\theta_{i}$ is the correlation level of the $i^{\text {th }}$ evaluation object and the reference sequence. The higher the correlation degree, the higher the similarity between the evaluation object and the reference

\footnotetext{
${ }^{1}$ Data preprocessing is the normalization of indicators in the index system. In this paper, the range transformation method is used to transform the data into dimensionless data between $[0,1]$.
} 
sequence (the best object) is, the better the evaluation effect is.

\subsection{Empirical Result}

The empirical part uses MATLAB software to perform operation. The weight of each index is specified in Table 2. It is shown in the table that the first three indexes with larger weight are the total import and export ratio of goods, the expenditure on education for birth and the number of Industrial Enterprises above the scale, which shows that the values of each sample are quite different on the above three indicators, so it has a great influence on the evaluation results.

Table 2 Using Entropy method to calculate the weight of each index

\begin{tabular}{c|c|c|c}
\hline name of index & weight(\%) & name of index & weight(\%) \\
\hline $\mathrm{X} 1$ & 9.37 & $\mathrm{X} 7$ & 7.86 \\
\hline $\mathrm{X} 2$ & 8.09 & $\mathrm{X} 8$ & 12.84 \\
\hline $\mathrm{X} 3$ & 17.71 & $\mathrm{X} 9$ & 2.09 \\
\hline $\mathrm{X} 4$ & 13.92 & $\mathrm{X} 10$ & 5.55 \\
\hline $\mathrm{X} 5$ & 4.86 & $\mathrm{X} 11$ & 11.1 \\
\hline $\mathrm{X} 6$ & 6.60 & & \\
\hline
\end{tabular}

On the basis of objective empowerment, the grey correlation analysis method is applied to calculate the similarity between the samples and the optimal reference sequence, and then the index is weighted to get the total evaluation score, and get the ranking in Figure 1. According to the results, Jiangsu and Guangdong ranked the top two in Higher Vocational Competitiveness and have higher scores, especially in Jiangsu Province, which is far more than the other provinces. Some provinces in the west, such as Tibet, Qinghai, Gansu and Ningxia, are at the end of the entire ranking. The competitiveness of Higher Vocational Colleges in various places has shown obvious differentiation.

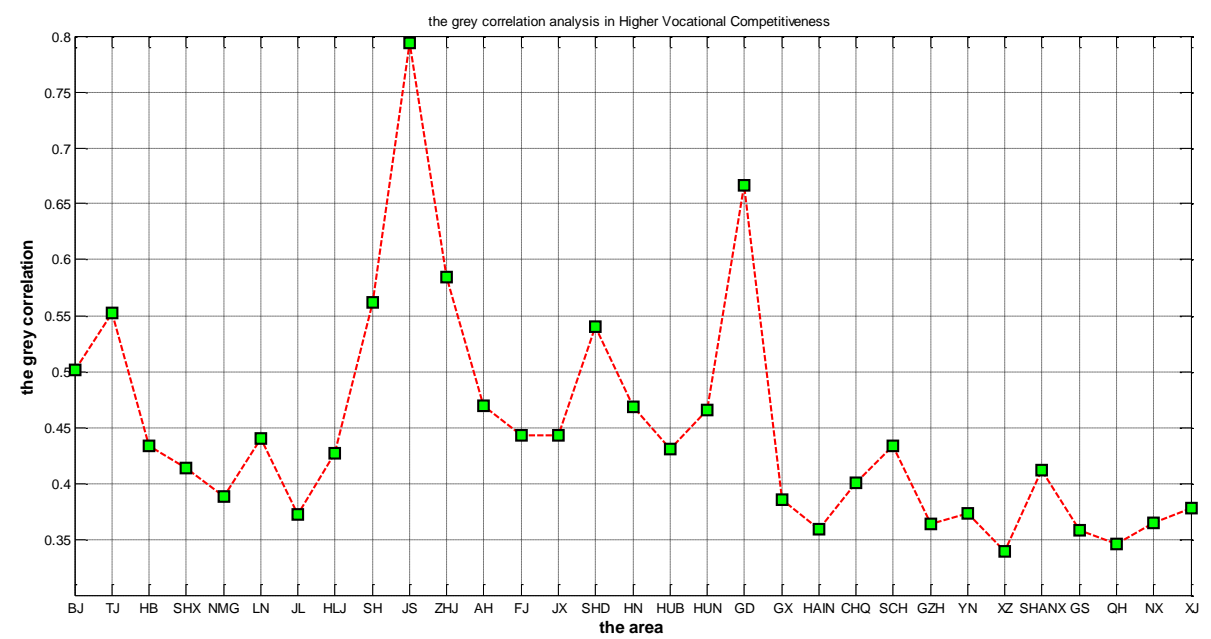

Figure 1 Higher vocational college education competitiveness comprehensive evaluation result

In order to decompose the competitive level of each region from the three dimensions of the index system, namely the environment of regional economic development, the scale of higher vocational education and the quality of higher vocational education, we have carried out the ranking calculation on the three levels of the sample area respectively. For details, see Table 3. 
Table 3 The evaluation result of Higher Vocational Education Competitiveness in various provinces and cities

\begin{tabular}{|c|c|c|c|c|c|}
\hline Region & $\begin{array}{c}\text { Regional } \\
\text { economic } \\
\text { developing } \\
\text { environment }\end{array}$ & $\begin{array}{c}\text { Higher } \\
\text { vocational } \\
\text { education } \\
\text { scale } \\
\end{array}$ & $\begin{array}{c}\text { Higher } \\
\text { vocational } \\
\text { education } \\
\text { Quality } \\
\end{array}$ & $\begin{array}{c}\text { Comprehen-siv } \\
\mathrm{e} \\
\text { competitive-ne } \\
\text { ss }\end{array}$ & $\begin{array}{c}\text { Comprehen-siv } \\
\mathrm{e} \\
\text { ranking }\end{array}$ \\
\hline Beijing & 0.618 & 0.391 & 0.391 & 0.501 & 7 \\
\hline Tianjin & 0.520 & 0.632 & 0.499 & 0.553 & 5 \\
\hline Hebei & 0.384 & 0.478 & 0.479 & 0.433 & 14 \\
\hline Shanxi & 0.354 & 0.497 & 0.423 & 0.414 & 18 \\
\hline Inner Mongolia & 0.386 & 0.392 & 0.388 & 0.388 & 21 \\
\hline Liaoning & 0.416 & 0.464 & 0.462 & 0.440 & 13 \\
\hline Jilin & 0.365 & 0.374 & 0.384 & 0.372 & 25 \\
\hline Heilongjiang & 0.356 & 0.470 & 0.534 & 0.427 & 17 \\
\hline Shanghai & 0.738 & 0.380 & 0.421 & 0.562 & 4 \\
\hline Jiangsu & 0.714 & 0.857 & 0.892 & 0.794 & 1 \\
\hline Zhejiang & 0.579 & 0.469 & 0.798 & 0.585 & 3 \\
\hline Anhui & 0.391 & 0.598 & 0.450 & 0.469 & 8 \\
\hline Fujian & 0.443 & 0.432 & 0.462 & 0.443 & 11 \\
\hline Jiangxi & 0.373 & 0.485 & 0.551 & 0.443 & 12 \\
\hline Shandong & 0.530 & 0.628 & 0.413 & 0.540 & 6 \\
\hline Henan & 0.399 & 0.591 & 0.436 & 0.469 & 9 \\
\hline Hubei & 0.390 & 0.467 & 0.473 & 0.431 & 16 \\
\hline Hunan & 0.373 & 0.581 & 0.505 & 0.466 & 10 \\
\hline Guangdong & 0.736 & 0.625 & 0.559 & 0.666 & 2 \\
\hline Guangxi & 0.364 & 0.407 & 0.399 & 0.385 & 22 \\
\hline Hainan & 0.360 & 0.363 & 0.347 & 0.359 & 28 \\
\hline Chongqing & 0.393 & 0.410 & 0.402 & 0.400 & 20 \\
\hline Sichuan & 0.383 & 0.466 & 0.504 & 0.433 & 15 \\
\hline Guizhou & 0.349 & 0.376 & 0.377 & 0.363 & 27 \\
\hline Yunnan & 0.353 & 0.396 & 0.384 & 0.373 & 24 \\
\hline Tibet & 0.337 & 0.345 & 0.333 & 0.339 & 31 \\
\hline Shanxi & 0.369 & 0.495 & 0.377 & 0.412 & 19 \\
\hline Gansu & 0.340 & 0.375 & 0.375 & 0.358 & 29 \\
\hline Qinghai & 0.343 & 0.341 & 0.357 & 0.345 & 30 \\
\hline Ningxia & 0.349 & 0.371 & 0.391 & 0.364 & 26 \\
\hline Xinjiang & 0.357 & 0.402 & 0.390 & 0.378 & 23 \\
\hline
\end{tabular}

In the evaluation system of the competitiveness of higher vocational education, the top five highest scores in "Regional economic developing environment" competitiveness are Shanghai, Guangdong, Jiangsu, Beijing and Zhejiang. All the provinces and cities are the developed regions in the East. The top five highest scores in "higher vocational education scale" competitiveness are Jiangsu, Tianjin, Shandong, Guangdong, and Anhui, especially Jiangsu, which scored far higher than other provinces and cities at this level. This shows that Jiangsu has obvious advantages in the investment in higher vocational education; the highest score in "higher vocational education quality" competitiveness is Jiangsu, followed by Zhejiang, and the scores of the two are far more than those in Guangdong and other provinces in the rear. In addition, in the evaluation of the competitiveness of the two higher vocational education, the performance of Shanghai and Beijing is not good. For example, Beijing ranks 23 and 20 in terms of "higher vocational scale" and "higher vocational quality". We think there are two main reasons: firstly, the two places have high level of urbanization, and the economic growth is mainly based on the third industries represented by modern service industries. At the same time, the main technical skills training talents in higher vocational colleges are concentrated in the production and manufacturing enterprises, so the 
industrial characteristics of the region are not suitable for the development of higher vocational colleges. Secondly, Nationally renowned universities in China which are focused on academic research center on Beijing and Shanghai. Therefore, educational resources are more inclined to such institutions, which lead to the development of higher vocational colleges is relatively slow, and the core competitiveness is not obvious.

According to the comprehensive score ranking, the competitiveness of Higher Vocational Education in 31 provinces and cities in China are classified in 4 levels:

Jiangsu and Guangdong have the strongest competitiveness, with a comprehensive score of more than 0.6. The total economic volume of Jiangsu and Guangdong ranks first in China, and the demand for high-quality skilled and skilled personnel is also greater, which is consistent with the training objectives of higher vocational talents. Take Jiangsu Province as an example, Jiangsu has always been a major province of education. It has invested heavily in education, and its higher vocational education and Sino foreign cooperation in running schools have always been in the most advanced place in China.

We list the regions with relatively strong competitiveness, which is the area with a comprehensive score of 0.5 to 0.6 as the second echelon, including Zhejiang, Shanghai, Tianjin, Shandong and Beijing. In this echelon, the comprehensive strength of Zhejiang is more balanced, especially in the quality competitiveness of higher vocational education; the other regions are slightly short, but since they are in more developed areas, their external development environment of higher vocational education is good, which provides space for the further development of higher vocational education. They should strengthen connotation development in the future.

The areas with ordinary higher vocational education competitiveness, which are the areas with a comprehensive score of 0.4-0.5, include Anhui, Henan, Hunan, Fujian, Jiangxi, Liaoning, Hebei, Sichuan, Hubei, Heilongjiang, Shanxi, Shaanxi. Higher vocational education in these areas still has much room for development. Among them, the scale advantages of Higher Vocational Education in Anhui, Henan and Hunan are relatively obvious. The quality advantages of Higher Vocational Education in Jiangxi, Heilongjiang and Hunan are relatively prominent. However, because there are some weak points in the comprehensive environmental development of the central and inland provinces, in order to improve their comprehensive competitiveness, it is necessary to improve based on their environmental characteristics and their own features.

Finally, the comprehensive score of the regions with weak competitiveness is below 0.4 , mainly in western regions such as Inner Mongolia, Guangxi and Xinjiang. Due to the influence of the remote region, they are relatively inadequate in terms of regional economic growth, the number of graduates, and the average education expenditure.

\section{Conclusion}

This article evaluates and sorts the competitiveness of higher vocational colleges through the construction of the evaluation index system of the competitiveness of higher vocational education, and uses the entropy weight method and grey relational analysis method. The empirical results can let us understand the competitive advantages of Higher Vocational Education in various places, and provide the policy basis for the balance of higher vocational education resources in the future, to make up for the advantages of the higher vocational education, and to promote the whole, long-term and sustainable development of higher vocational education.

\section{Acknowledgment}

Fund Program: The project of Education Science Planning of Fujian Province in 2017 (FJJKCGZ17-02); School teaching reform project of Xiamen City Vocational College in 2016(JGXM-02). 


\section{References}

[1] Sun Jingshui. International comparison of China's educational competitiveness, Education and Economics, vol.2, pp.1-3,2001.

[2] Wu Yuming. An Empirical Study on the competitiveness of regional education in China, Education and Economics, vol.3, pp. 15-19, 2002.

[3] Chen Yan, Li Yujing, Fang Wei, Cheng Yu \& Zhang Qi Wu. Comparative study on international competitiveness of China's vocational education, Education Research, vol.6, pp. 63-68, 2009.

[4] Fang Yong. Comparison of vocational education competitiveness between China and Switzerland and Its Enlightenment, Vocational Education Forum, vol.16, pp. 89-90, 2016.

[5] Hu Binwu, Ye Meng, Pang Yao, Xiao Han \& Wu Jie. An empirical test of the balance and efficiency of the development of Secondary Vocational Education -- Based on the inter provincial panel data analysis, Education Research, vol.1, pp.75-82, 20117.

[6] Cui Kuiyong, Zhao Sasa. Evaluation index system of comprehensive competitiveness of National Demonstrative Higher Vocational Colleges, China higher education research, vol.10, pp. 88-90, 2012.

[7] Qiu Junping, Chai Wen. Competitiveness evaluation and analysis of Chinese Higher Vocational Colleges in 2016.Journal of Chongqing University (social science edition), vol.3, pp. 70-76, 2017. 